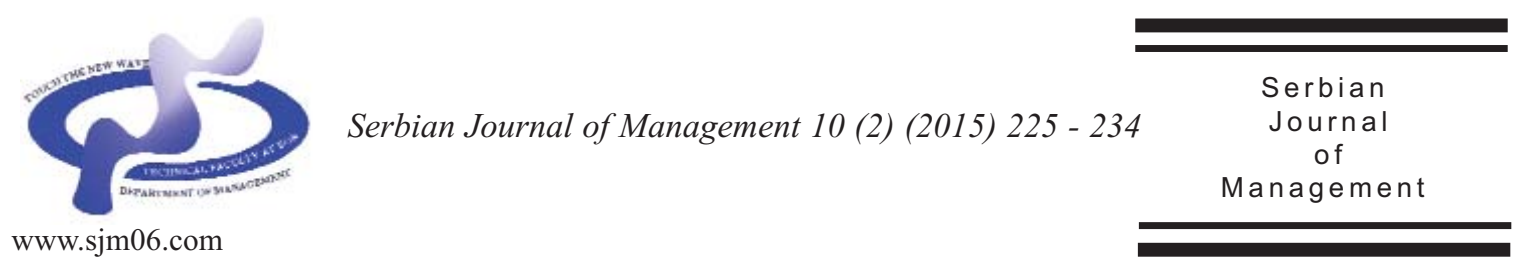

\title{
QUALITY MANAGEMENT TOOLS APPLYING IN THE STRATEGY OF LOGISTICS SERVICES QUALITY IMPROVEMENT
}

\author{
Agnieszka Czajkowska ${ }^{a *}$ and Renata Stasiak-Betlejewska ${ }^{b}$

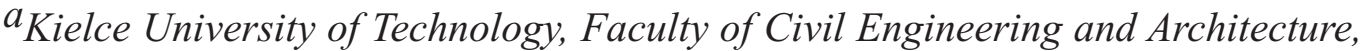 \\ Department of Strength of Materials and Concrete Structures, al. Tysiaclecia Państwa \\ Polskiego, 25-314 Kielce, Poland \\ ${ }^{b}$ Czestochowa University of Technology, Institute of Production Engineering, ul. \\ Dąbrowskiego 69, 42-201 Częstochowa, Poland \\ (Received 16 April 2015; accepted 26 August 2015)
}

\begin{abstract}
Combination of factors such as: properly organized logistics process, lack of nonconformities, transport damages avoiding and transport in accordance Just In Time idea significantly reduces costs and streamlines the entire production process. This paper proposes the quality management tool for the logistics services assessment based on the results obtained in the selected company operating in Eastern Europe. Customers' expectations and perceptions were compared using the SERVQUAL method that concerns the service quality assessment in five areas such as: materiality, reliability, promptness, competency and empathy. The research method SERVQUAL allows assessing the service quality level and identifying company areas that requires corrective actions within the improvement process.
\end{abstract}

Keywords: service, logistics, quality management, improvement strategy, SERVQUAL

\section{INTRODUCTION}

Quality improvement is one of the most popular strategy of the contemporary enterprises. Process improvement programs that do not refer directly to increase its competitive advantage, they are doomed to fail. Walmart, FedEx, McDonald's and other companies, which are struggling to have their products and services have always been of the high quality while maintaining competitive pricing, must continually

\footnotetext{
* Corresponding author: a_czajkowska@o2.pl

DOI:10.5937/sjm10-8095
} 
improve their operational processes (Power, increase.

2015).

Key element of the service quality level improvement is research methodology applying for the quality level identification and taking appropriate corrective actions in order to improve enterprise activity in the individual service areas. Specifying quality problems in the service company requires searching problems that occur in the individual service areas related to the customer and stakeholders satisfaction.

The contemporary logistics offers services its customers such as: the supply, the production, the distribution and the disposal (Meller, 1994). The low level of logistics services thus involves nonconformities occurrence in each of the mentioned areas. Since it can be seen much more nonconformities, whose causes result from improperly provided logistic services. In this situation, it is necessary to strive to improve the logistics process, which will reduce costs associated with the improper quantity or the quality of provided raw materials, delays, etc.

Logistics processes continue to evolve, and its importance is growing, which is associated with (Danzas, 2002; Witkowski, 2002):

- globalization of the production and the economic movement,

- the service sector importance rise,

- growing importance of recycling,

- shortening of the product life cycle,

- technical advancement in transport,

- innovativeness increase in the supply, production and distribution processes,

- development of transport corporations that form a global suppliers and distribution network,

- the competition intensify increase,

- the increase of the customers
There is growing importance of the logistics processes quality issue. Quality issue has many definitions that have one thing in common - the product complies with the specifications and customers' satisfaction. In case of the service, the quality is associated with the fulfilment of customers' expectations. Services provided by individual providers for recipients are determined by its utility, what is described as the advantage in the exchange process they hope to achieve.

Scholars Mentzer, Gomes and Krapfe (1989) believe that logistics services should be evaluated from the customer point of view, they also divided logistics services and marketing services into customers (Marketing CustomerSer vice, MCS) and physical distribution services (Physical Distribute Service, PDS) (Mentzer et al., 1989).

The transport service quality level is controlled by direct contact with customers in case of claims and it should also prevent carrier opportunism. Such control is based on traditional communication methods and so cannot be attached to the collaboration issue (Stojanović \& Aas, 2015; Pavlović et. al., 2014).

Quality assurance systems offer a lot of methods and tools that help to prevent lowquality services, including logistics services. There are two types of activities: prevention and corrective, which identify nonconformities and determine the cause responsible for nonconformities occurrence (Bratu, 2013). Commitment to quality of logistics services can be carried out according to the following steps:

1. Identification of customers' needs and expectations. In determining customer requirements for logistics services following 
7W rules (in Polish 7 Right rules) can be used as proposed in the literature (Simchi-Levi et al., 2000; Gajewski, 2007):

- the relevant goods,

- in the right quantity,

- at the right time,

- at the right place,

- with the right quality,

- the relevant costs,

- the right customer.

In the implementation of the first step, a matrix diagram can be applied. It will determine the relationship between customers' expectations (that should be ordered) and determine its validity (because not all features of the service have the same meaning).

In some foreign countries, the evaluation of logistics services is partially operated from the evaluation of the operational aspects of logistics, measure orders, instant delivery ratio and distribution ratio of nondamaged items, known as "7Rs"theory (Zhang \& Zhang, 2010).

2. Determining of logistics services elements, that do not satisfy customers (e.g. because of the delivery delay) on the basis of the complaint.

3. Identification of customers' dissatisfaction causes with quality management tools applying. There can be applied Ishikawa diagram, which allows identifying causes of nonconformities (Borkowski \& Čorejowă, 2004; Maleszka \& Zalewski, 2005). The other useful quality management tool is diagram of the relationship, that allows searching relationships between the main problem and the reasons affecting nonconformities occurrence (Maleszka \& Zalewski, 2005). This diagram is a bit like Ishikawa diagram, with one difference - apart from the links to the "cause-effect" it also illustrates the relationship "cause-cause" (Maleszka \& Zalewski, 2005; Borkowski \& Czajkowska, 2006).

4. Corrective action taking to avoid the identified causes of reduced quality of logistics services with quality management tools applying such as: taxonomy diagram

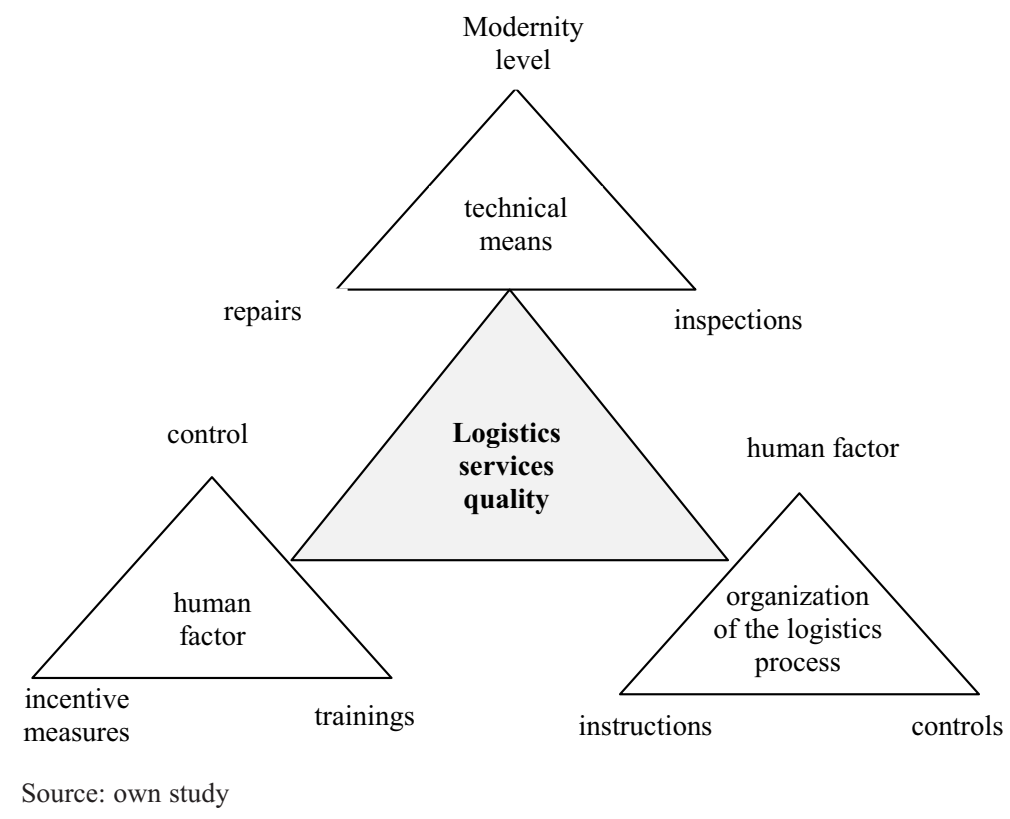

Figure 1. Factors affecting the logistics services quality 
that shows in detail ideas aimed at the logistics process improvement (Miller, 2011; Borkowski \& Czajkowska, 2006) and the FMEA method. FMEA method is used at the process design stage and it can reduce the losses associated with the improper conduct of the same process (Borkowski \& Czajkowska, 2006; Meller, 1994). Its aim is therefore to identify and assess the risks associated with vulnerabilities occurring during the logistics process (Meller, 1994).

Figure 1 shows factors affecting the logistics services quality.

Factors affecting the logistics services quality include: organization of the logistics process, technical and human factors.

\section{MATERIALS AND METHODS}

Service organizations, which care about quality of services, should recognize the clients' requirements and measure their satisfaction (Stasiak-Betlejewska et al., 2014). Identification of the service performance in terms of customers' expectations and their perception is useful in the organization process improvement. Customers' opinion helps organization to identify its strengths and weaknesses and form an appropriate strategy.

Service quality measurement models in different correlations have been elaborated for different research models needs (Moore, 1987; Heywood-Farmer, 1988; Beddowes et al., 1988; I ash, 1988; Philip \& Hazlett, 1997; Robledo, 2001; Lewis, 1989) since the organizational human resources management needs organizational arrangement (Stacho et al., 2013; Jost et al., 2012). The most enduringly popular, widely cited and best researched method of assessing service quality is Servqul developed by Parasuraman et al. (1985, 1988). Servqual method is focused on identifying perceived quality, which is a customer's judgment about the excellence of a service (Zeithaml, 1987).

Servqual methodology is tried and tested methodology primarily within the commercial sector (Kaye \& Dyason, 2013). This methodology presents the differences (gaps) related to some different levels of expectation and perceptions result from the clients' and the organization point of view within five service quality criteria:

- materiality that concerns appearance of physical facilities, equipment, personnel and communication materials,

- reliability that includes ability to perform the promised service dependably and accurately,

- promptness that result in willingness to help clients/students and provide prompt service,

- competency related to knowledge and expertise of employees and their ability to convey trust and confidence,

- empathy including caring, individualized attention the organization provided to customers.

The research findings were collected in the logistics company that provides comprehensive services including freight forwarding, transportation, warehousing, repacking and insurance. To test the logistics services quality Servqual method was used. This method is the most commonly used method for reviewing the service quality level. Servqual method is to assess the difference between customers' expectations and their experiences of (Wszendybył \& Borkowski, 2004; Zeithaml et al., 1990). This difference is both expectations were higher than the actual experience of the service recipient, as well as if the experience exceeded the expectations formulated earlier 
(Zeithaml et al., 1990; Mazur, 2001; Wszendybył, 2005). The study was carried out on the basis of questionnaires filled out by 350 customers of the chosen logistics company.

\section{RESULTS AND DISCUSSION}

The aim of the study was to assess the level of quality of services provided by logistics. The results of the survey are presented in Table 1.
Total arithmetic measure of the logistics service quality (Servqual):

$\mathrm{S}=\Sigma \mathrm{R}_{\mathrm{Sr}} / 5=-0.94$

The weighted averages for different areas of service quality are presented in Table 2.

The overall level of service logistics quality level in the analyzed company is 0.94 and it proves that customers' expectations exceed their actual experience in terms of the service quality level.

Table 1. Customers' assessment of the logistics company services quality in terms of customers' expectations (E) and customers' perception $(P)$ and the final satisfaction level $(S)$

\begin{tabular}{|c|c|c|c|}
\hline LOGISTICS SERVICE QUALITY AREAS & \multirow[b]{2}{*}{$\mathbf{E}$} & \multirow[b]{2}{*}{$\mathbf{P}$} & \multirow[b]{2}{*}{$\mathbf{S}$} \\
\hline MATERIALITY & & & \\
\hline $\begin{array}{l}\text { 1. The company has a storage suitable for storing goods } \\
\text { of customer. }\end{array}$ & 7.0 & 6.8 & -0.20 \\
\hline 2. The company has a proficient means of transportation. & 7.0 & 6.48 & -1.22 \\
\hline 3. Packages are applied to the goods the customer. & 7.0 & 6.79 & -1.21 \\
\hline 4. Applicable documentation is free of errors. & 6.6 & 5.8 & -0.8 \\
\hline $\mathrm{W}=19.3$ & & \multicolumn{2}{|c|}{$\mathrm{R}_{\mathrm{sr}}=-0.86$} \\
\hline RELIABILITY & & & \\
\hline 5. Keeping services attainment deadlines. & 6.72 & 6.50 & -0.22 \\
\hline 6. The goods are delivered to the right place. & 6.56 & 6.12 & -0.44 \\
\hline 7. Service costs are competitive. & 6.69 & 4.91 & -1.78 \\
\hline $\begin{array}{l}\text { 8. The customer can rely on a comprehensive service. } \\
\qquad \mathrm{W}=23.4\end{array}$ & 6.66 & \multicolumn{2}{|c|}{$R_{\text {sr }}=-0.69$} \\
\hline \multicolumn{4}{|l|}{ PROMPTI!ESS } \\
\hline 9. Customers can rely on the fast execution of the service. & 5.32 & 4.67 & -0.65 \\
\hline 10. The company quickly responds to your order. & 6.12 & 5.54 & -0.58 \\
\hline $\mathrm{W}=1.9$ & & \multicolumn{2}{|c|}{$\mathrm{R}_{\mathrm{sr}}=-0.62$} \\
\hline COMPETEİCY & & & \\
\hline 11. Customer receives the correct product. & 6.01 & 5.19 & -0.82 \\
\hline 12. Customer receives the product with appropriate quality. & 6.12 & 5.04 & -1.08 \\
\hline 13. The customer's goods are supplied in the right quantities. & 5.78 & 5.10 & -0.68 \\
\hline 14. Employees have the expertise. & 6.01 & 6.68 & 0.67 \\
\hline 15. Customers can rely on the touch at any time of the day. & 4.61 & 3.68 & -0.93 \\
\hline 16. Any delays are compensated for to the client. & 6.20 & 5.16 & -1.04 \\
\hline 17. If necessary, the company offers warehousing. & 6.3 & 6.0 & -0.3 \\
\hline $\mathrm{W}=25.2$ & & \multicolumn{2}{|c|}{$\mathrm{R}_{\mathrm{sr}}=-0.59$} \\
\hline EMPATHY & & & \\
\hline 18. Every client is treated individually. & 5.64 & 3.26 & -2.38 \\
\hline 19. Working hours are convenient for customers. & 6.23 & 4.78 & -1.45 \\
\hline 20. The staff really care about each customer. & 5.87 & 3.36 & -2.51 \\
\hline 21. Employees are committed to customer satisfaction. & 6.27 & 4.48 & -1.79 \\
\hline 22. Employees understand the specific needs of customers. & 6.24 & 4.62 & -1.62 \\
\hline $\mathrm{W}=14.4$ & & \multicolumn{2}{|c|}{$R_{\text {sr }}=-1.95$} \\
\hline
\end{tabular}

Rśr $=$ the average value for the final logistics service quality in the analyzed area

$\mathrm{W}=$ the validity of the individual logistics service areas

Source: own study 
Table 2. The weighted averages for individual logistics service areas

\begin{tabular}{lccc}
\hline \multicolumn{1}{c}{ Servqual area } & $\begin{array}{c}\text { The validity level in } \\
\text { the clients' opinion } \\
\text { (W) }\end{array}$ & $\begin{array}{c}\text { Average } \\
\text { P-O }\end{array}$ & $\begin{array}{c}\text { The weighted } \\
\text { averages }\end{array}$ \\
\hline Materiality & 19.3 & -0.86 & -16.60 \\
Reliability & 23.4 & -0.69 & -16.15 \\
Promptness & 17.9 & -0.62 & -11.09 \\
Competency & 25.2 & -0.59 & -15.05 \\
Empathy & 14.4 & -1.95 & -28.08 \\
\hline
\end{tabular}

Source: own study

Analyzing results obtained in the second part of the Servqual research aimed to determine individual service five areas importance level (in accordance to customers' opinion) for services provided by the analyzed logistics company, show that the most important service quality area in the customers' opinion is "Competency" ( $\mathrm{W}=$ 25.2) and the least important is "Empathy" $(\mathrm{W}=14.4)$. Area "Reliability" was assessed as the second area within the importance level $(\mathrm{W}=23.4)$.

Competency concerns all company activities that follow $7 \mathrm{~W}$ rules related to the appropriate quality of the service as a consequence of supply of the correct product in the right quantities to the right customer and the right place. It should be noted, that area "promptness" related to fast execution of the service and company's responds to customers' order was located on the third position of importance in accordance to customers' opinion $(\mathrm{W}=17.9)$.

"Empathy" area. The largest negative difference between customers' expectations and their experience relates to this particular area, the respondents did not consider it very important.

Logistics company best meets customers' expectations in the area "Speed" (- 11.09) and in the area "Competency" (- 15.05). Logistics company in most cases meet the payment deadline of the service. In the customers' opinion supply should be done with no mechanical defects, delivered to the right place at the right time. These requirements are contained in the area "Competency". Elements of the "Competency" were specifically assessed in order to determine which elements of this dimension must be improved. (Figure 2).

The analysis of Figure 3 shows that

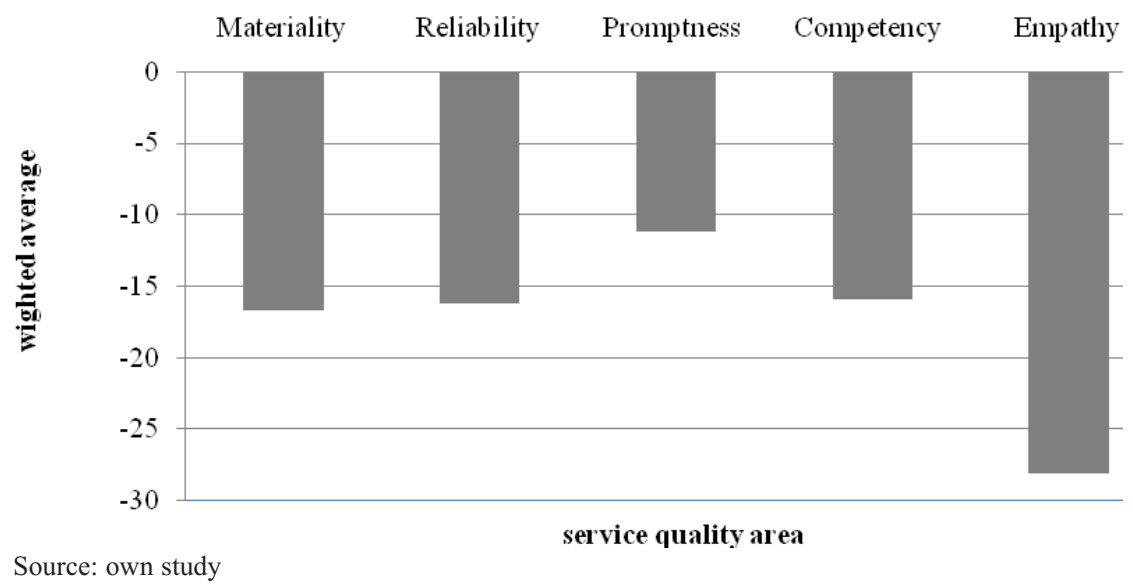

Figure 2. Weighted averages for the different quality areas of services provided by analyzed logistics company 


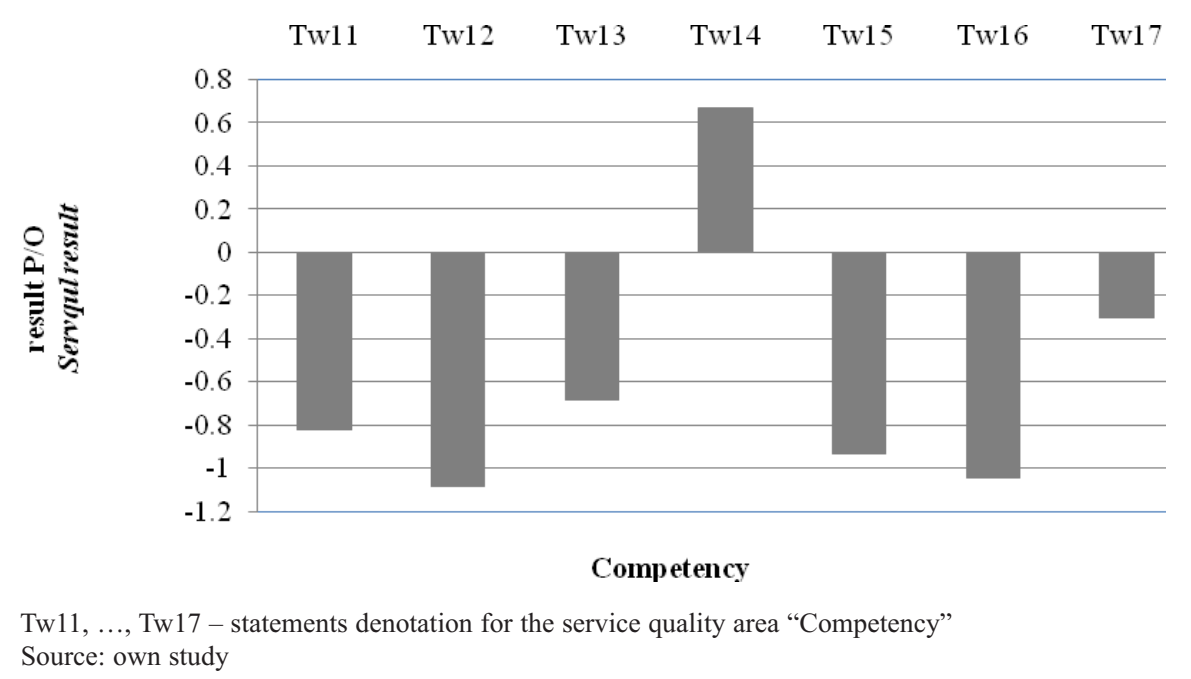

Figure 3. Research results analysis for service quality area "Competency"

analyzed logistics company in only one case of customer's opinion exceeded customers' expectations. Customers are surprised by the workers' expertise (TW14) in the analyzed logistics company. Employees using their work experience propose solutions that positively surprise customers. Other factors do not differ significantly from customers' expectations, but unfortunately do not meet them completely.

Some research results confirm commonly obtained results in the service quality level analysis (Stasiak-Betlejewska et al., 2014; Zhang, 2011; Dobos \& Knut, 2006). Investigation conducted among customers of American logistics companies concluded 9 logistics service indicators related mostly with staff communication (Dobos \& Knut, 2006).

Zhang (2011) proved in the research that potential quality and results quality have the greatest impact on logistics service quality. In the mentioned research results (Zhang, 2011) it was concluded, that logistics services improvement requires company's employee training system what is related to the staff competency level (high standard qualifications) supporting customer's satisfaction. Staff expertise and attitude with regard to customers' orders and claims is one of the crucial element that affects the final logistics service quality level.

In the context of research results review, obtained research findings underline the great role of the staff knowledge and its skills for the final quality level assessment with regard to evaluation of the logistics services. Instead of the technical equipment, competency is noted as the crucial element of the logistic service quality since it affect on the appropriate service delivery.

\section{CONCLUSIONS}

Logistics processes are still attributed to new functions. These processes are not only connected with the function of transport. Wider range of services means the impact on other areas of the enterprise outside of the supply. At a time when the effectiveness, quality, low cost decide whether the company will continue on the market more and more attention is paid to the logistics processes. Logistic processes affect many processes involved in the finished product 
manufacturing including all stages from the supply by providing raw materials and semifinished products in the manufacturing process up to the final product to the customer.

The analysis of study results shows that the area that is most important for customers of logistics company is "Competency" (25.2), while the least important is "Empathy". The small difference between customers' expectations and their perceptions is presented in the final research result (-11.09).

The aim of the service quality level identification by Servqual method applying is identifying factors that are key element in the service organization processes improvement. Servqual precise gaps (difference) that require corrective actions.

Research results underline the quality improvement need in the area "Empathy" and "Materiality", what is connected with improving company facilities, its equipment and relations with customers. Those elements should be properly managed by the applying quality management tools that allows customer relationship management strategy improving through increase of workers commitment. "Competency" area of logistics service quality is supportive element for the "Materiality" area improvement because knowledge and workers experience help with identifying of appropriate corrective actions. The training introduction should be organized in the analyzed company since it is priority in any organization improvement and development.

\section{Acknowledgement}

This work is related to the scientific program of the "Improving quality of processes, products and services" BW 615/201/07 supported by Polish Ministry of Science and Higher Education.

\title{
ПРИМЕНА АЛАТА МЕНАЏМЕНТА КВАЛИТЕТОМ У СТРАТЕГИЈИ УНАПРЕЪЕЊА КВАЛИТЕТА ЛОГИСТИЧКИХ УСЛУГА
}

\author{
Agnieszka Czajkowska, Renata Stasiak-Betlejewska
}

\section{Извод}

Комбинација фактора као што су: адекватно организовани логистички процес, изостанак недостатака, избегавање оштећења при транспорту и транспорт према идеји ЈиТ, значајно смањују трошкове и унапређују читав производни процес. Овај рад предлаже алат менаџмента квалитетом за процену логистичких услуга, на основу резултата истраживања, о одабраним источно европским компанијама. Очекивања купца и остварени учинак су упоређени применом методе "SERVQUAL", која обухвата процену квалитета услога у пет области као што су: материјално стање, поузданост, брзина, компетенције и емпатија. Овај истраживачки метод омогућава процену нивоа квалитета услуге и идентификацију области у компанијама који захтевају корективне акције у оквиру унапређења процеса.

Кључне речи: услуга, логистика, управљање квалитетом, стратегија унапређења, "SERVQUAL" 


\section{References}

Beddowes, P., Gulliford, S., Knight, M., \& Saunders, I. (1988). Service Success! Who Is Getting There? Operations Management Association, University of Nottingham, Nottingham.

Borkowski, S., \& Czajkowska, A. (2006). Analysis of nonconformities responsible for the low quality of the castings. VII International Scientific Conference. New Technologies and achievements in metallurgy and material engineering. Częstochowa, 80-83. (in Polish).

Borkowski, S., \& Čorejowă, T. (2004). Instruments of problems solving in management. Publishing House of the Management and Marketing Higher School. Sosnowiec. (in Polish)

Bratu, M.S. (2013). Improvements in assessing the forecasts accuracy - a case study for Romanian macroeconomic forecasts. Serbian Journal of Management, 8 (1), 53-65.

Danzas, L. (2002). Danzas Deutschland holding GmbH, Düsseldorf. 2.

Dobos, I., \& Knut, R. (2006). A production/recycling model with quality consideration. International Journal of Production Economics, 104, 571-579.

Gajewski, A. (2007). Introduction into quality management. Publishing House of Malopolska Economics Higher School. Tarnów. 28-29. (in Polish)

Heywood-Farmer, J. (1988). A conceptual model of service quality. International Journal of Operations \& Production Management, 6 (3), 5-9.

Jost, M., Oblak, L., Zupancic, A., \& Kos, J. (2012). Use of elements of the marketing communications mix in Slovenian furniture companies. Wood and furniture industry in times of change - new trends and challenges. $5^{\text {th }}$ International Conference on Wood and Furniture Industry in Times of Change - I ew trends and challenges (WoodEMA). Trnava. Slovakia. Jun 06-08 2012, 30 - 34.

Kaye, M., \& Dyason, M. (2013). Delivering "more for less" in the public sector: a criminal justice system case study. Proceeding of 14 International Symposium on Quality, Quality against recession. Rovinj, 571-581.

Lewis, B.R. (1989). Quality in the service sector - a review. International Journal of Bank Marketing, 7 (5), 4-12.

Maleszka, A., \& Zalewski, R. (2005). Quality - Quality Management. Centre of Leaders Creating. Skierniewice. 103. (in Polish)

Mazur, J. (2001). Service marketing management. Centre of Consulting and Information. Difin. Warszawa. (in Polish)

Meller, A. (1994). Method of failures modes and effects analysis (FMEA). Organization Review, 2, p16. (in Polish)

Mentzer, J.T., Gomes, R., \& Krapfel, R.E. (1989). Physical distribution service: a fundamental marketing concept. Journal of The Academy of Marketing Science, 17 (1), 53-62.

Miller, P. (2011). Systemic quality management. Difin. Warszawa, 483-485. (in Polish)

Moore, C.D. (1987). Outclass the competition with service distinction. Mortgage Banking, 47 (11), 24-32.

I ash, C.A. (1988). A question of service: action pack. Business Management Programme. Hotel and Catering Industry Training Board. National Consumer Council, London.

Parasuraman, A., Zeithaml, V.A., \& Berry, L.L. (1985). A conceptual model of service quality and its implications for future research. Journal of Marketing, 49 (4), 41- 
50.

Parasuraman, A., Zeithaml, V.A., \& Berry, L.L. (1988). SERVQUAL: a multipleitem scale for measuring consumer perceptions of service quality. Journal of Retailing, 64 (1), 12-40.

Pavlović, D., Todorović, M., Mladenović, S., \& Milosavljević, P. (2014). The role of quality methods in improving education process: Case study. Serbian Journal of Management, 9 (2), 219-230.

Philip, G., \& Hazlett, S. (1997). The measurement of service quality: a new 'P-C$\mathrm{P}$ ' attributes model. International Journal of Quality \& Reliability Management, 14 (2/3), 260-286.

Power, B. (2015). When the process improvement is significant from the point of view of strategy? Harvard Business Review Polska. (in Polish)

Robledo, M.A. (2001). Measuring and managing service quality: integrating customer expectations. Managing Service Quality, 11 (1), 22-31.

Simchi-Levi, D., Kaminsky, P., \& Simchi-Levi, E. (2000). Designing and managing the supply chain. Irwin McGraw Hill, International Editions. 1.

Stacho, Z., Urbancová, H., \& Stachová, K. (2013). Organisational Arrangement of Human Resources Management in Organisations Operating in Slovakia and Czech Republic. Acta Universitatis Agriculturae et Silviculturae Mendelianae Brunensis, 61 (7), 2787-2799.

Stasiak-Betlejewska, R., Kaye, M., Dyason, M., Stachová, K., \& Urbancová, H. (2014), The services quality level assessment at the technical university using the Servqual method. Journal on Efficiency and Responsibility in Education and Science, 7 (3-4), 53-58.

Stojanović, D.M., \& Aas, B.O. (2015).
Transport outsourcing and transport collaboration relationship - the risk hedging perspective. Serbian Journal of Management, 10 (1), 33-49.

Witkowski, J. (2002). Logistics companies to global and national development challenges. Logistics enterprises in the transition. Publishing House. Wroclaw. p240. (in Polish)

Wszendybył, E. (2005). Methods of the hotel services quality measuring. [In:] Borkowski, S. Products and services quality management. Manager Publising House PTM. Warszawa. (in Polish)

Wszendybył, E., \& Borkowski, S. (2004). The quality of hotel services from the point of customer's view. [In:] Stankiewicz, J. The organization in conditions of growing competition. Publishing House of Zielonogórski University. Zielona Góra. (in Polish)

Zhang, C. (2011). Logistics Service Quality Evaluation. Communications in Information Science and Management Engineering, 1 (1), 16-21.

Zhang C., \& Zhang L. (2010). Logistics Service Quality Evaluation. Scientific Research. The Conference on Web Based Business Management.

Zeithaml, V. (1987). Defining and Relating Price, Perceived Quality and Perceived Value. Marketing Services Institute Report N o. 87-101. Marketing Services Institute. Cambridge.

Zeithaml, V.A., Parasurman, A., \& Berry, L.L. (1990). Delivering Quality Service. Balancing customer perceptions and expectations, The Free Press. 